\title{
Dr. Philip D. Bedford
}

Dr. P. D. Bedford died suddenly at the age of 48 when he was reaching the peak of his career at Oxford, where he was a consultant physician at the Cowley Road Hospital and a clinical lecturer in medicine at the university.

After a distinguished career at school in Leeds, where he gained a medical scholarship in the university, Philip Derek Bedford graduated M.B. Ch.B. with honours in 1939. He then held the posts of house-surgeon, house-physician, and resident medical officer at Halifax General Hospital. Joining the R.A.F. for service as a medical officer in the Second World War, he served until 1946, in India, Burma, France and the U.K. After his war service he became medical registrar at the General Infirmary, Leeds, for three years. He showed his keenness by going to Guy's Hospital for six months on study leave before being appointed registrar and then senior registrar in the Oxford Geriatric Unit and Cowley Road Hospital, part of the United Oxford Hospitals. He proceeded M.D. in 1947 and took the M.R.C.P. in 1950.

At Oxford his clinical ability was rapidly recognized and he was appointed as consultant to the Cowley Road Hospital in 1954 as well as to other hospitals of the Oxford Regional Hospital Board. He played a full part in the teaching activities of the United Oxford Hospitals and was appointed clinical lecturer and tutor in medicine to Oxford University. Besides his interest in the fields of clinical medicine, he made a special study of geriatrics, and made many valuable contributions to the medical literature, several being published in the British Medical Journal. In 1958 he was honorary secretary of the Section of Geriatrics at the Annual meeting of the B.M.A. in Birmingham.

Philip Bedford's death will be keenly felt in Oxford. His was an exceptionally sharp mind, active, inquisitive, bursting with vitality and with a passionate search for truth. This, coupled with his highly critical sense, meant that his intellectual standard was exceptionally high.

Nevertheless he never chose to sit on Olympic thrones to "deliver" judgements. On the contrary, his door was always open, in the hospital or at his home. No time was too long, no hour too late for him to give his full attention to any caller. Callers there always were, many. He was not only an excellent physician but had a very erudite brain with an unusually sharp logical sense and a quick, clear grasp of any problem presented to him.

He was an excellent teacher. Many will remember his ward rounds, the informal conversations after rounds over a cup of tea, and the ease and clarity with which he would unfold some complicated case. It was well known that one of the best preparations for a Membership examination was to spend some time on ward rounds with Philip Bedford. He could not only teach the subject, he could teach people to think. He taught easily, unobtrusively, and elegantly; his vocabulary and his wit were rich and excellent.

But, above all he was a man with real compassion and understanding. There was no human problem of any nature to which he was not prepared to give his full attention, advice and help. It was immediately a help to discuss a problem with him; his crystal clear analysis of the basic essentials and his full, warm, understanding sympathy made him a father-confessor figure to many of his friends. And he was a friend - a friend of few words, self effacing, and shy to show 
emotions, but a friend utterly dependable and constant, in luck and adversity, a very real and faithful friend. It is hard to realize that this incredibly vital brilliant and warm person is not with us any more. His writings will remain, his teaching will live in the thoughts of his pupils, and his work will persist in the hospital. The warmth of his personality will live in our memory, but the friend will be bitterly missed and mourned by many. 